\title{
Genetic Macular Dystrophy
}

National Cancer Institute

\section{Source}

National Cancer Institute. Genetic Macular Dystrophy. NCI Thesaurus. Code C140264.

Macular dystrophy that is related to a change in a gene. 